\title{
SYSTEM DYNAMIC MODELLING FOR ENVIRONMENTAL PROCESSES: A CASE STUDY OF LAKE ENGURE
}

\author{
Mārcis Zariṇš" ${ }^{\#}$ Andra Blumberga, Māris Klaviṇš, and Viesturs Melecis \\ Faculty of Geography and Earth Sciences, University of Latvia, Raina bulv. 19, Rīga, LV-1586, LATVIA; \\ zarc@inbox.Iv \\ \# Corresponding author
}

Contributed by Māris Kḷavinš

\begin{abstract}
This focus of the study was on system dynamic models that could be useful for modelling environmental processes in Lake Engure. The paper considers the system dynamic model development principles, the most important elements and structure. The aim of the study was to describe possible methods of ecosystem process modelling that allow to represent the actual state of ecosystems and provide opportunities to predict further processes. The methods of ecosystem modelling considered in the paper reveal interactive factors of anthropogenic and environmental processes that influence changes in ecosystems. System dynamic models indicate not only interactions between various factors in the environment but also the most important driving forces. These models are based on flowchart and algorithm systems, which represent changes using mathematical functions in a graphic or tabular form. In the case study of Lake Engure, connections between factors that influence ecosystems in the study area were identified. Specialised software, PowerSim Studio Academic 9.0, was used for modelling. The model consists of qualitative and multifactor data of Lake Engure ecosystems, such as water chemical, physical and hydrological parameters, biological, ornithological and other data collected in the study area. Development of this modelling method will make it possible to evaluate the impact of various processes on biological diversity changes in the study area and to identify the most important problems. Furthermore, this method could improve environmental management practice in the surrounding municipalities, and it will also be possible to make similar models of ecosystem quality in other regions.
\end{abstract}

Key words: system dynamic modelling, ecosystem quality ecosystem modelling, environmental changes, validation.

\section{INTRODUCTION}

Lake Engure is the largest water basin in the western coastal area of the Gulf of Riga, which developed due to processes in several stages of the Baltic Sea evolution. The first basin influencing the area of Lake Engure was the Baltic Ice Lake. The area of the sloping Baltic Ice lake Plain (25-30 to $8-10 \mathrm{~m}$ above the sea level) is presently located between the Baltic Ice Lake and Litorina Sea coastline (Eberhards and Saltupe, 2000).

Since 1948, the bird population in Lake Engure was increasing, but since the system of socialism collapsed in Latvia it has decreased more than ten times. This problem at Lake Engure could be caused by decreasing availability of bird nesting places beginning in the 1990s. This problem is connected with changes in the socioeconomic situation in Latvia and decrease of fish recycling and fur farm activities, which led to a decrease of anthropogenic food (Vìksne et $a l .$, 2011). The sub-model "Birds in Lake Engure" was designed for evaluating changes in the bird population in time and the ecological processes associated with chemical, physical, hydrological, and other important environmental processes. Changes in bird populations in the lake drainage basin can also cause changes of other ecosystems. Changes in water levels can create a decrease in overgrown area size. These areas are the main nesting sites for birds, as they prefer nesting on islands and in marshes. Overgrowing lake areas provide conditions for increasing volumes of biomass that can be used as food by various ecological groups, e.g., birds and fish (Viksne, 1997).

System dynamic and also conceptual modelling in the forecasting of environmental processes is a new method for evaluating and forecasting changes in ecosystems. Our modelling performed for Lake Engure is an example of such modelling. Conceptual models are better for representing various ecological processes, while system dynamic models are more efficient for representing interactions of various factors. Chart diagram building principles and advanced software have been used in the modelling process. System dynamic and conceptual modelling could become a useful tool for coping with environmental management issues and 
sues and evaluating the most important environmental problems related to ecological processes in the drainage basin of Lake Engure. A negative side of conceptual and system dynamic models is that they required a large scope of data that is sometimes hard to find. This could result in the model showing inaccurate results, compromising the attainment of the aim of the study (Moody, 2005).

The DPSIR (Drivers-Pressures-States-Impacts-Responses) conception could be used as an instrument for developing system dynamic and conceptual models, and it could be useful for studying details of these models. This concept forms the base platform that indicates driving forces, pressures, states, impacts and response components (Fig. 1) (Haberl et al., 2009).

The DPSIR model is a widely used model for defining human and environmental interactions and it can be used for visualising environmental and socio-economic impacts (Burkhard and Müller, 2008). The DPSIR model is being used as the base conception in developing a system dynamic model for the drainage basin of Lake Engure.

The system dynamic method evaluates changes in more than one subsystem. Sometimes it can be a useful tool for increasing environmental quality. The main principles of subsystem development are connected with study of driving forces and the structure of base ecosystems. This connection provides opportunities for evaluating impacts in various ecosystems. For developing a system dynamic model of ecosystems, there must be well-defined stock values, flows, feedback links, borders of system and other interactions (Blumberga, 2010a). Regarding the drainage basin of Lake Engure, there is a need for qualitative data of the lake water physical and chemical state, surface water and underwater plant stock changes, and the bird, fish and mammal populations, and their dynamics and changes also need to be evaluated. Meteorological and hydrological conditions and ecological management activities also make important input data for developing system dynamic models (Costanaz and Vainov, 2001).

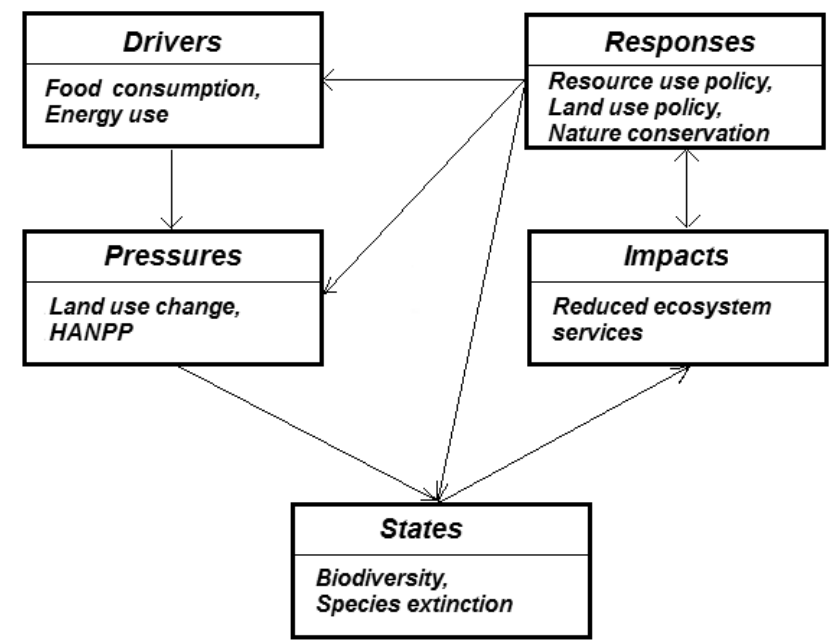

Fig. 1. Socio-economic biodiversity pressures and drivers - flow chart of a conceptual model of a long-term ecological research platform based on the DPSIR concept (Haberl et al., 2009).
The aim of this research is to evaluate the possibilities to use system dynamic modelling to develop a sub-model "Birds in Lake Engure" and also to study research fields that provide ecosystem modelling solutions and promote model effectiveness. The objectives of this research were to evaluate conceptual and system dynamic modelling possibilities for ecological modelling, to clarify significant factors that interact with ecosystem quality of Lake Engure, to develop the sub-model "Bird in Lake Engure", and to clarify the quality and accessibility of the necessary data for ecosystem modelling.

\section{MATERIALS AND METHODS}

The system dynamic methodology is related to the traditional economical thought, but in this case appropriate data collection and terminological methods are applied. The whole system response structure is characterised as a causal feedback loop. Response loops can be in normal balance when they are tending to negative and positive directions at the same time, and this is a confirmation that the system is working. Balanced loops are tended towards the main outcome; however, if there is a system interruption, then the system has a tendency to return to the balanced position. When the negative feedback loop increases after temporary system interruptions, a chain of events develops that disrupts the system balance (Smith and Ackere, 2002).

Development of a system dynamic model involves five modelling steps: 1) definition of the problem; 2) development of a dynamic hypothesis; 3) definition of the model and simulation; 4) testing of the model; 5) drafting of a policy and testing (Fig. 2).

System thinking is a process of trial and error. In literary studies, the results of system thinking appear simple and easy to understand, while in reality the system is complicated. System dynamic modelling is a creative process, and it can aid in developing new and innovative ideas (Forester, 1971).

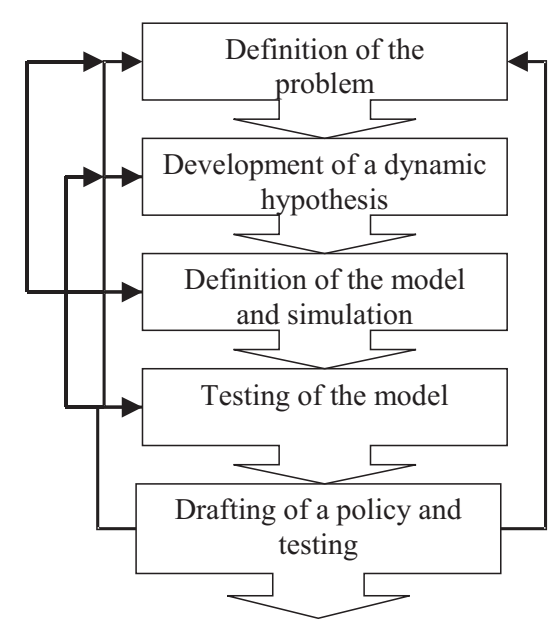

Fig 2. The system dynamic modelling process (after Blumberga, 2010a). 


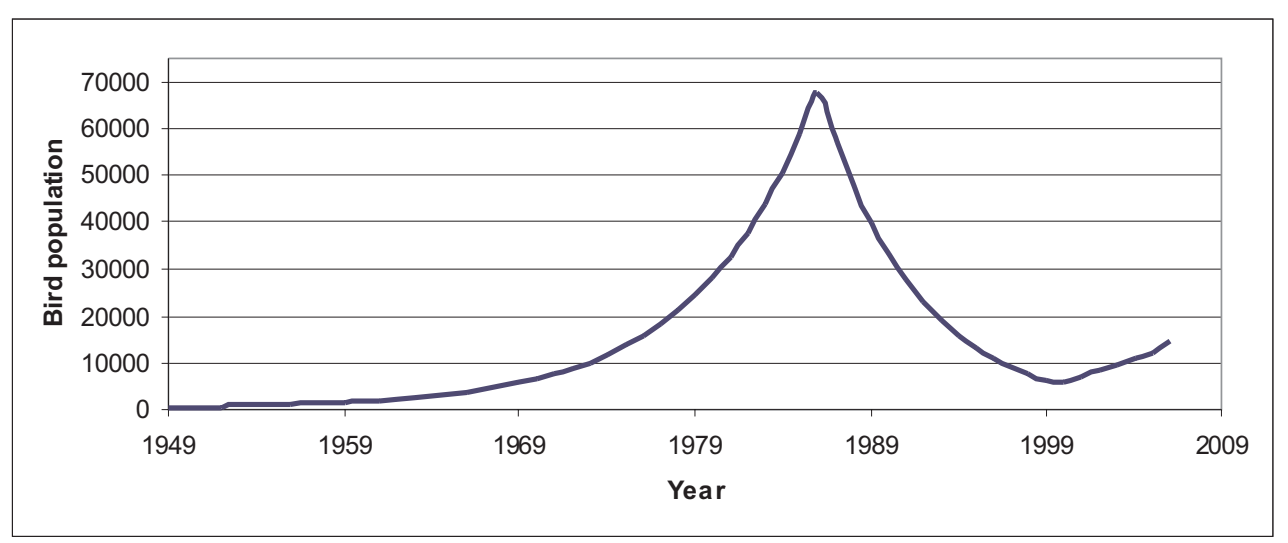

Fig 3. Observed data of bird stock in the drainage basin of Lake Engure (Viksne, 2011).
The problem at Lake Engure was that bird nesting sites had dramatically decreased at the beginning of the 1990s. This problem is related to changes in the economic situation in Latvia and decrease of fish recycling. This means that the anthropogenic food source for birds was seriously affected (Vīksne et al., 2011). The sub-model "Birds in Lake Engure" was designed for evaluating changes of the ornithofauna in time and the ecological processes associated with fluctuations of chemical, physical, hydrological, and other important environmental processes. Changes in bird stock values in the lake area can also have an impact on the health of other ecosystems. Changes in hydrological conditions lead to changes in water levels, which in turn lead to a decrease of the overgrown area, which is the main nesting area for birds, as they prefer nesting on islands and in marshes. Overgrowing lake areas provide conditions for increasing volumes of biomass that can be used as food by various ecological groups, e.g., birds and fish (Vīksne, 1997).

The dynamic hypothesis of this sub-model is that the resulting output graph, which shows the ornithofauna changes in time, should conform with the observed data. Observed data of ornithofauna have been collected since 1949 until today. In a period of about sixty years, bird stock values have fluctuated by tens of thousands. On condition that both graphs maintain the same tendency and that the simulation graph does not have serious mistakes, this model should be capable of functioning (Fig. 3).

Specific software has to be used for model simulation. The chosen PowerSim software is effective for the purpose of representing ecological and economic impacts. This software is used in the dynamic hypothesis development process, and the hypothesis is modified for the software to simulate critical points of the actual system. Mathematical interactions and equations between alternating parameters are developed in the model definition phase and, after that, these equations are inserted in a computer simulation. In this way, the system element output graph is obtained, and it can be compared with the base scenario behaviour. If the two graphs differ, it means that the model has failed. If the simulated graph coincides with the observed time scenario graph, it means that the model has been developed correctly (Anderson and Johnson, 1997).
The basic elements for developing system dynamic models are: stock values, flows, feedback loops, precisely defined borders of the modelled ecosystem, and different causal relations which connect various system elements. One of the typical stocks is the quantity of population or amount of material in a specific territory. Examples of typical flows are populations or birth/death rates. The links between flows, stocks and feedback loops depend on one another (Fig. 4) (Blumberga, 2010a).

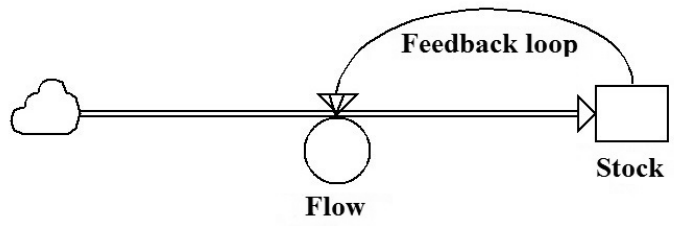

Fig. 4. Interactions between flows, stocks and feedback loops (after Blumberga, 2010a).

Mathematical equations of models are simple algorithmic equations and integral equations. One of the main conditions for defining equations is to assign equal measurements for system elements. Data for model simulation are achieved from literature research (Table 1).

A simulation model was created for a period of 55 years, from 1949 to 2005, employing the dynamic hypothesis which was made earlier. The structure of the system dynamic sub-model "Birds in Lake Engure" consists of the main bird stock values in Lake Engure, the inflow of bird natality and three outflows that describe bird mortality related to natural and anthropogenic food availability, bird mortality from hunting and from predator assaults (Fig. 5). One of the inflows that describes increase in the total bird population is obtained by multiplying the bird birth rate by the total number of birds in the simulation step. The total bird birth rate is described by a bird nesting site effect on bird natality. The outflow describing bird mortality from hunting in the simulation year is obtained by multiplying the percentage of birds hunted by the total number of birds in the simulation step. The bird mortality from hunting depends on the total quantity of birds in the lake drainage ba$\sin$. The outflow describing the bird mortality from predator assaults is a constant value that represents the number of birds killed in one simulation year. In a possible compre- 
hensive model of the drainage basin ecosystems of Lake

SUB MODEL “BIRDS IN LAKE ENGURE” BASE VALUES

\begin{tabular}{|c|c|c|c|c|}
\hline Parameter & Label & Amount & Unit & Author \\
\hline $\begin{array}{l}\text { Density of available } \\
\text { anthropogenic food }\end{array}$ & $\begin{array}{l}\text { Ant food } \\
\text { dens }\end{array}$ & 0.12 & $\mathrm{~kg} / \mathrm{bird}$ & $\begin{array}{l}\text { Erickson et al., } \\
2005\end{array}$ \\
\hline Lake square & Lake sq & 413000000 & $\mathrm{~m}^{2}$ & $\begin{array}{l}\text { Strautnieks un } \\
\text { Grine, } 2011\end{array}$ \\
\hline Nests & Nests & 1001 & sites & Viksne et al., 2011 \\
\hline $\begin{array}{l}\text { Proportionally } \\
\text { hunted birds in one } \\
\text { year }\end{array}$ & Hunted \% & 9 & $\%$ & LU BI report, 2009 \\
\hline $\begin{array}{l}\text { Quantity of birds } \\
\text { killed by predators }\end{array}$ & Killed birds & 327 & $\mathrm{n}$ & Viksne et al., 2011 \\
\hline $\begin{array}{l}\text { Normal bird birth } \\
\text { rate }\end{array}$ & $\begin{array}{l}\text { Norm birth } \\
\text { rate }\end{array}$ & 26.5 & $\%$ & Sherry et al., 2000 \\
\hline $\begin{array}{l}\text { Total quantity of } \\
\text { predators }\end{array}$ & Predators & 8 & $\mathrm{n}$ & Viksne et al., 2011 \\
\hline $\begin{array}{l}\text { Total quantity of } \\
\text { birds }\end{array}$ & Birds & 400 & $\mathrm{n}$ & Viksne et al., 2011 \\
\hline $\begin{array}{l}\text { Proportion of birds } \\
\text { that eat fish }\end{array}$ & $\begin{array}{l}\text { Prop birds } \\
\text { of fish }\end{array}$ & 82.75 & $\%$ & Viksne et al., 2011 \\
\hline $\begin{array}{l}\text { Proportion of birds } \\
\text { that eat zoobenthos } \\
\text { and zooplankton }\end{array}$ & $\begin{array}{c}\text { Prop birds } \\
\text { of zoo }\end{array}$ & 17.25 & $\%$ & Viksne et al., 2011 \\
\hline $\begin{array}{l}\text { Average lifespan } \\
\text { of birds }\end{array}$ & Avg lifespan & 23.25 & years & Desholm, 2009 \\
\hline Fish density & Fish dens & 0.025 & $\mathrm{~kg} / \mathrm{m}^{2}$ & Brizs, 2012 \\
\hline $\begin{array}{l}\text { Zooplankton and } \\
\text { zoobenthos density }\end{array}$ & Zoo dens & 0.04 & $\mathrm{~kg} / \mathrm{m}^{2}$ & Anonīms, 2009 \\
\hline
\end{tabular}

Engure, there will be a larger body of data about the mammal predator lifestyle in the region. This factor may cause a chain reaction in the model and effect the sub-model "Birds in Lake Engure". The outflow describing bird mortality related to the available natural and anthropogenic food sources is obtained by multiplying the total number of birds in the simulation step by the coefficient of the total bird death rate in the simulation step. There are two possibilities: one is when birds feed only from natural food sources, another is when they feed from natural and anthropogenic food. In the former case, the total coefficient, which consists of other coefficients like bird lifetime, fish and zoobenthos density in the lake, is multiplied with the total number of birds in the simulation step. In the latter case, the total coefficient, which is made up of other coefficients, like bird lifetime, fish, zoobenthos density in the lake and available anthropogenic food, is multiplied with the total number of birds in the simulation step.

The conceptual scheme of the sub-model "Birds in Lake Engure" is based on one positive feedback loop and three negative feedback loops. The positive feedback loop describes the increase in the total bird quantity that is connected with the availability of nesting sites - a key element for providing an uninterrupted bird population. The negative feedback loop, which represents the bird mortality from hunting, is a causal closed feedback loop. This loop does not have elements of limitation, and it depends only on the total quantity of birds. The feedback loop that shows the

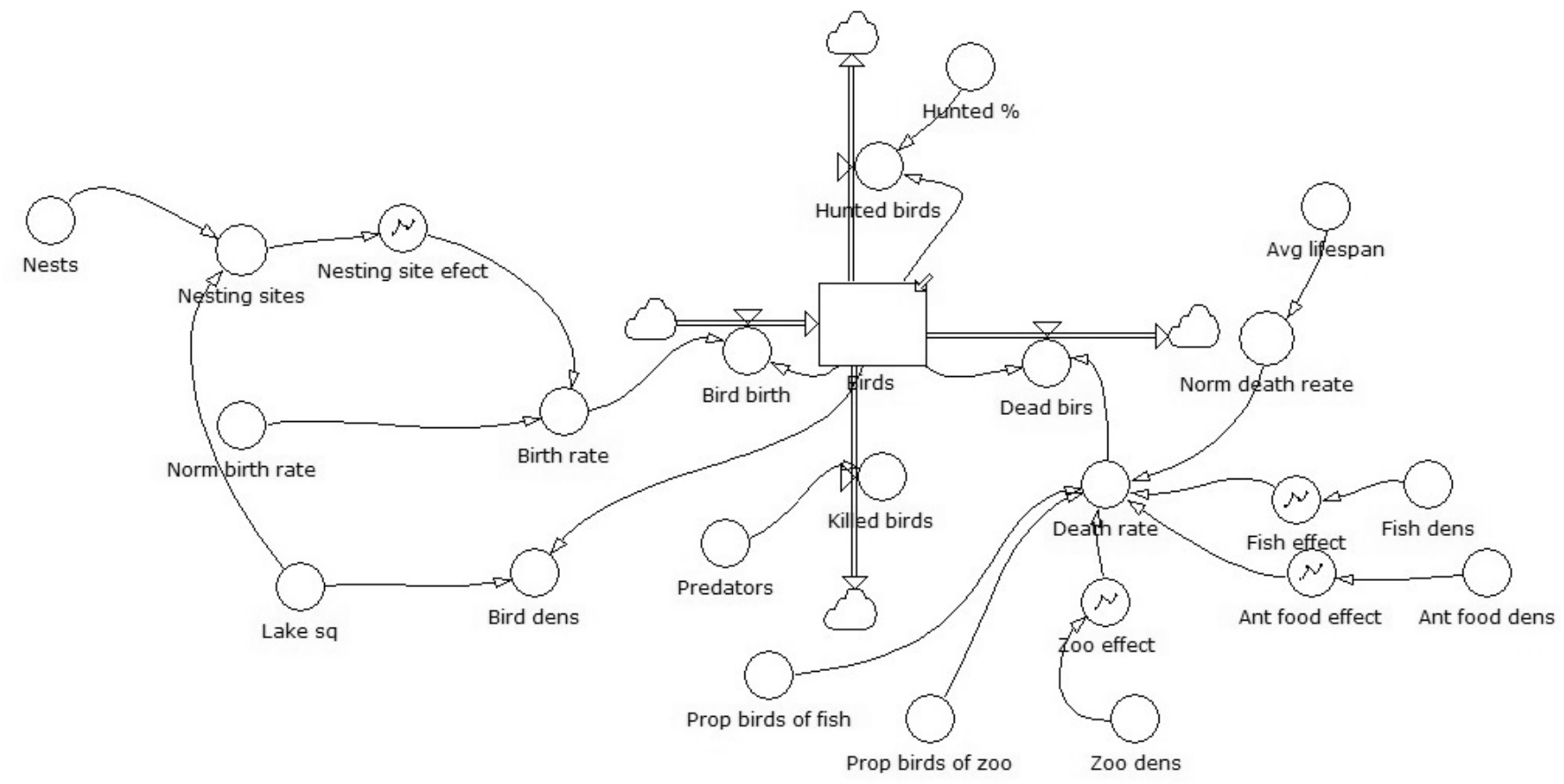

Fig. 5. The system dynamic sub-model "Birds in Lake Engure" scheme: Ant food dens - density of available anthropogenic food; Ant food effect anthropogenic food effect on bird death rate; Avg lifespan - average lifespan of birds; Bird birth - total value of bird birth; Bird dens - bird density; Birds total quantity of birds; Birth rate - bird birth rate; Dead birds - total quantity of dead birds; Death rate - bird death rate; Fish dens - fish density; Fish effect - fish density effect on bird mortality; Hunted \% - proportionally hunted birds in one year; Hunted birds - total quantity of hunted birds; Killed birds quantity of birds killed by predators; Lake sq - lake square; Nesting site effect - nesting site effect on bird birth rate; Nesting sites - available nesting sites; Nests - nests; Norm birth rate - normal bird birth rate; Norm death rate - normal bird death rate; Predators - total quantity of predators; Prop birds of fish proportion of birds that eat fish; Prop birds of zoo - proportion of birds that eat zoobenthos and zooplankton; Zoo dens - zooplankton and zoobenthos density; Zoo effect - zooplankton and zoobenthos effect on bird death rate. 


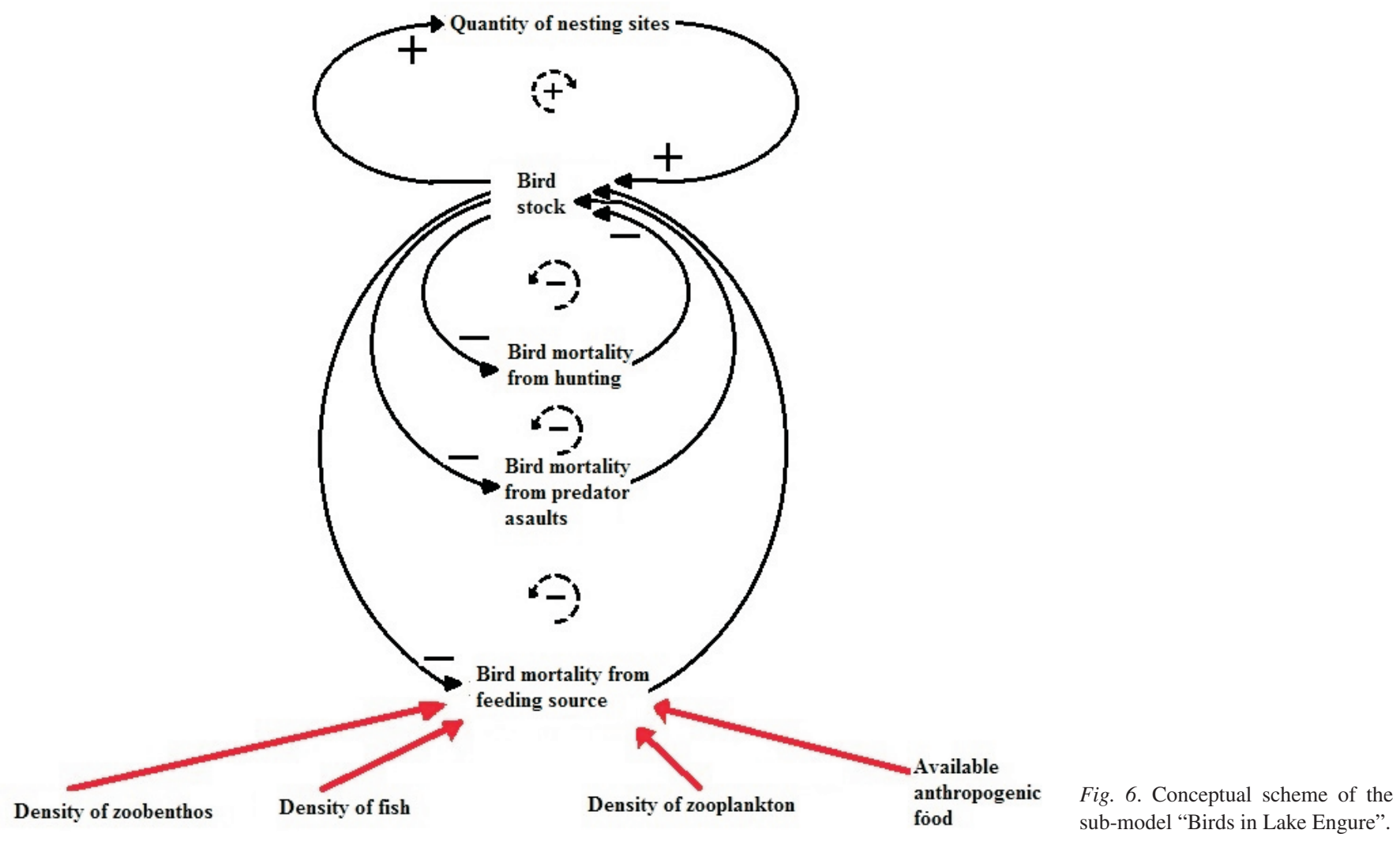

bird mortality from predator assaults depends only on the total quantity of birds. The negative feedback loop, which describes the bird mortality relating to the available food base, depends on the densities of zoobenthos, fish and zooplankton and amount of potentially available anthropogenic food (Fig. 6).

When the simulation was started, the anthropogenic food was not available and the size of the total bird population was stable. Starting with the $11^{\text {th }}$ year of simulation, the anthropogenic food source was unlimited, meaning that the bird mortality from a lack of any food source was decreasing. Starting with the $37^{\text {th }}$ simulation year, the anthropogenic food source no longer existed, and bird feeding returned to a natural level; the bird mortality also returned to the level at the starting point of the simulation.

The total bird mortality depending on the death type at the starting point of simulation was almost constant. When the quantity of birds increased, the bird mortality from various death types increased proportionally. If the quantity of predators in the sub-model is not connected with another submodel, then the bird mortality from predator assaults remains constant throughout the simulation period.

\section{RESULTS}

The system dynamic model of the drainage basin of Lake Engure contains a complex ecosystem analysis, which characterises ecosystem parameters. To improve the development of this particular system dynamic model, sub-models were developed for explaining various ecosystem elements. We studied possibilities for developing a specific sub- model of ornithofauna population dynamics in the drainage basin of Lake Engure. The sub-model of bird population changes shows bird stock changes in time, as well as impacts of natural and anthropogenic food stocks. The impacts of predators and hunters on bird population stocks are also considered.

The hunted bird quantity in the simulation is dependent on the entire bird population. Every year, about $9 \%$ of birds were shot. A dramatic increase in the bird population was observed till the $37^{\text {th }}$ simulation year. In 26 of these years, anthropogenic food sources were unlimited and bird mortality from the lack of food sources was proportionate to the total bird population. Starting with the $37^{\text {th }}$ year of simulation, the bird mortality dramatically increased because the anthropogenic food sources were almost the only food sources for birds for those 26 years. After that, the bird mortality from the lack of food sources increased almost by fifteen times. Starting with the $50^{\text {th }}$ year of simulation, all food sources were stabilised and the bird mortality returned to a normal level, as in the simulation starting point (Fig. 7). If we exclude hunting and predator assaults from the simulation, then we can see that the presence of food sources is the main factor of qualitative population dynamics. Other potential factors (not included in this version of the model) with a significant impact on the bird population dynamics are serious diseases, situations when the natural lifestyle of birds is radically changed, and dramatic changes of water levels in Lake Engure.

The total bird birth rate in years till the $37^{\text {th }}$ simulation year was exponentially growing, and this trend is related to the uninterrupted food source coverage. 


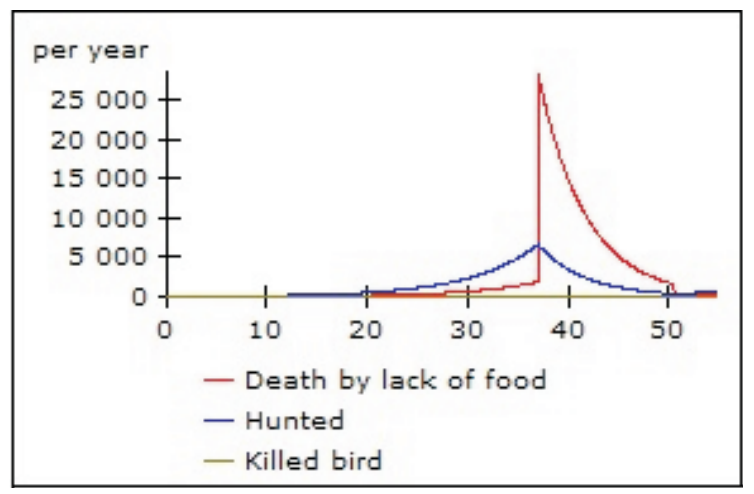

Fig. 7. Bird mortality by various factors.

After the $37^{\text {th }}$ simulation year, when the anthropogenic food source was no longer available, large quantities of birds did not have sufficient food sources and the bird populations decreased. In almost thirteen years, the total population of birds decreased from 20000 to 1000 birds - a decrease by more than twenty times. After that, the bird stock value started to increase, reaching 1500 birds, which means that the base food sources were sufficient if other food sources remain unchanged (Fig. 8). This quantity of birds is sufficient to sustain the bird populations in the long term.

In the simulation period, the maximum proportion of bird mismatches constitutes $7 \%$ of the observed data. After the $37^{\text {th }}$ year of simulation, the tendency of bird population dynamics matches in both graph lines. They show a dramatic decrease in the bird population. At the same time, after the $40^{\text {th }}$ simulation year, we can observe an opposite tendency - the simulation graph shows a lower value than it was in the real time-data. At this point, the difference between the simulation and observed data is about $34 \%$.
It is possible that at that time in the environment there was some undervalued food source that compensated the anthropogenic food source deficit. This situation could be caused by a lower hunted bird quantity or a lower number of birds killed by predators.

Development of this sub-model indicates that it is possible to develop system dynamic models of various population dynamics, although there are many complicated factors that have impacts on these populations and ecosystems in the long term. These factors might be water level changes compared with the sea level, precise interactions between bird population and provision with food sources and some other specific data. To determine the total biomass of all plants, many sampling plots are needed, and they should be inspected every year. At present, this parameter is defined approximately, and this could cause serious lack of precision in simulating this sub-model.

Sub-model "Water plants in Lake Engure". In the study period, there were attempts to develop sub-models of other Lake Engure ecosystems. One of them was the sub-model "Water plants in Lake Engure" (Fig. 9), defining precise stock of biomass for underwater and water surface plants. Dynamic changes in water plants are difficult to define because of the inflow and outflow mutability. For precise defining of inflows and outflows, annual monitoring data for a long time period are required. To define the outflow of water plant mechanical decrease, annual data on cut and pastured volumes of plants are required. In this way, it is possible to calculate changes in the underwater plant and surface water plant dynamics. To define natural decomposition of plants, a study of literature sources on similar ecoregions would be needed (Birzs, 2011).

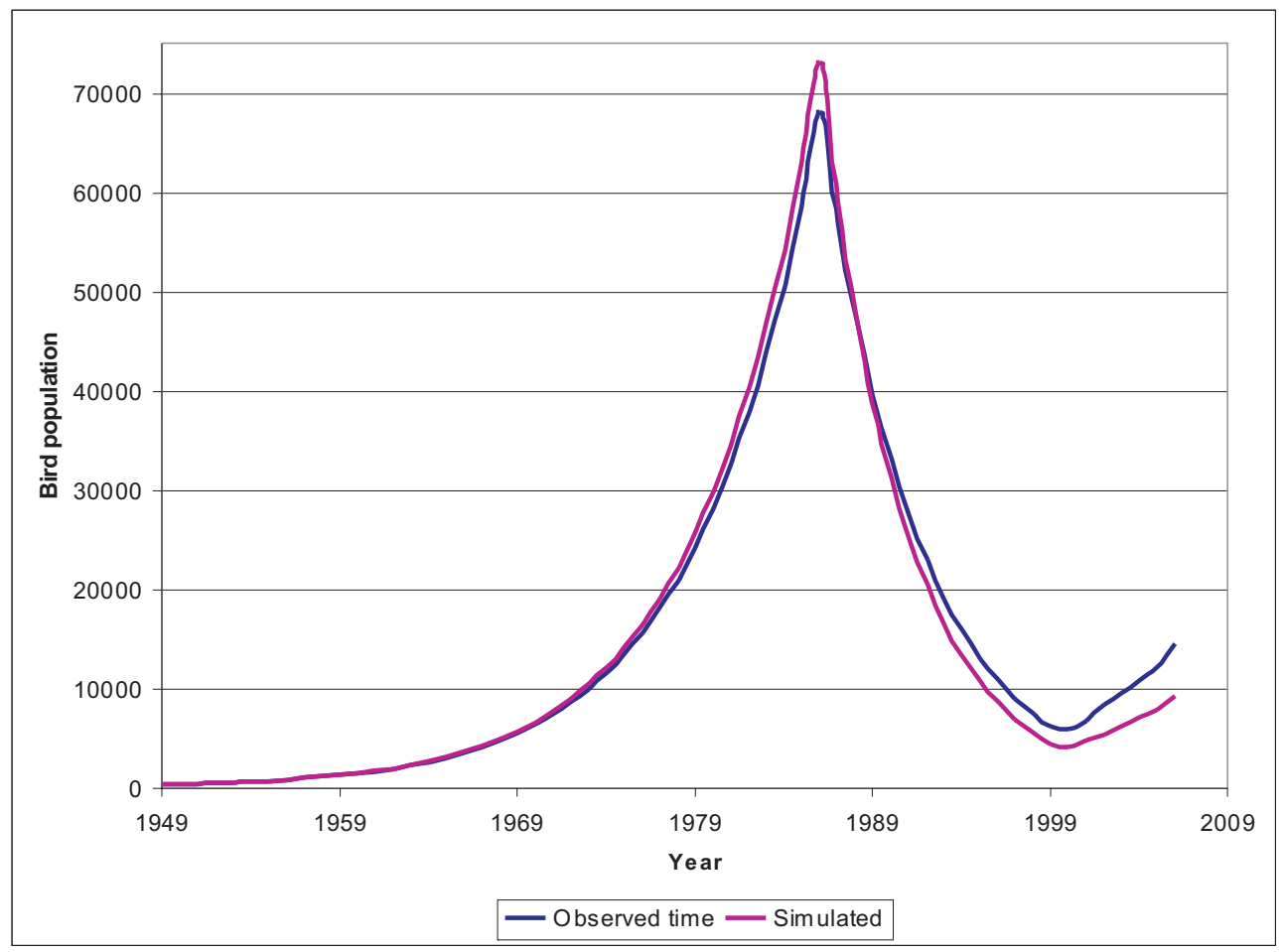

Fig. 8. Bird population changes in observed time and in simulation. 


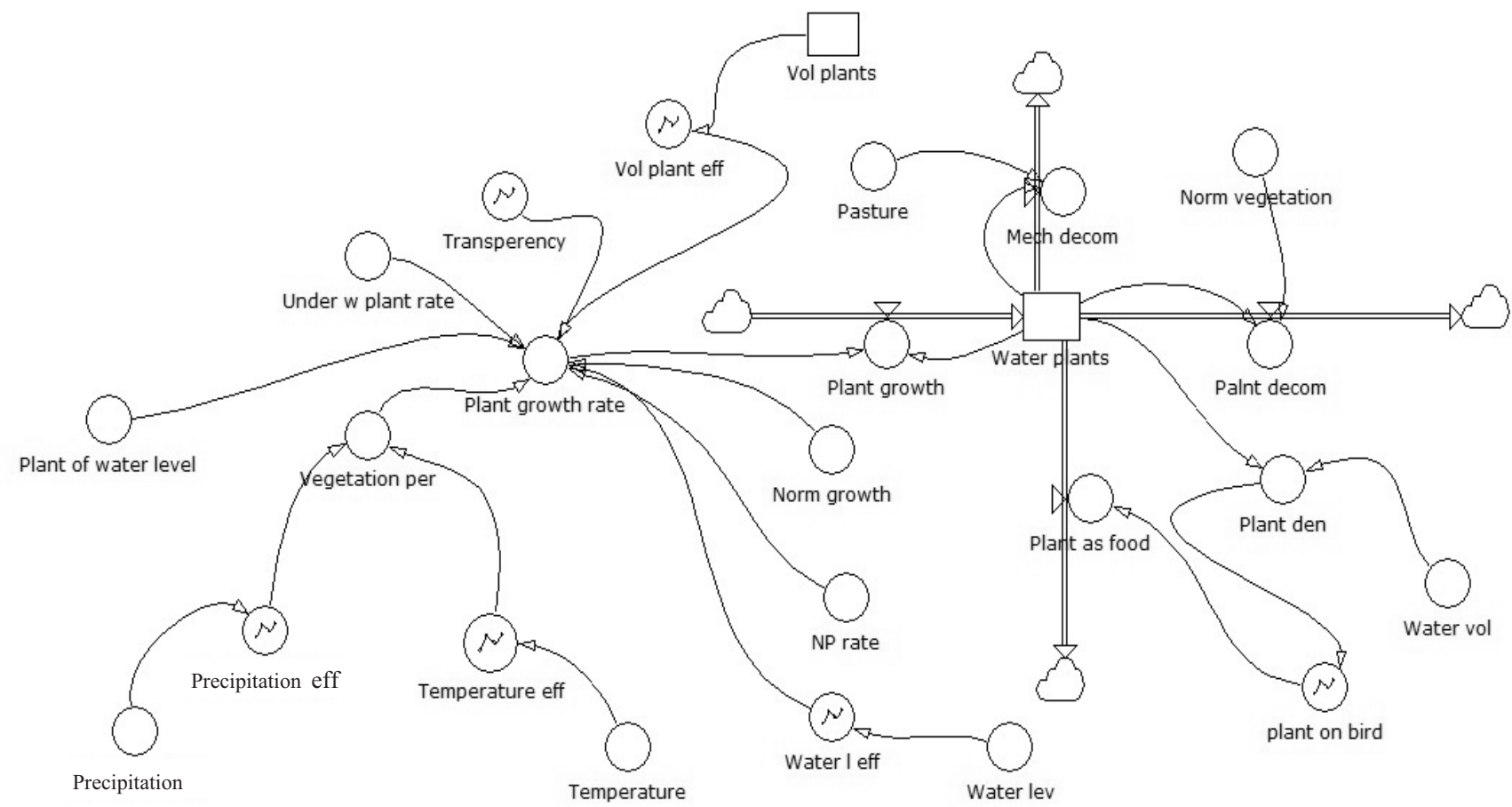

Fig. 9. The system dynamic sub-model "Water plants in Lake Engure" scheme: Mech decom - mechanical decompostion; Norm growth - normal water plant growth; Norm vegetation - normal water plant vegetation period; NP rate- N/P rate; Plant decom - water plant decompostion; Pasture - pasture; Plant as food - water plants as food source; Plant den - water plant density; Plant growth - water plant growth; Plant growth rate - water plant growth rate; Plant of water level - water plant interaction with water level; Plant on bird - water plant amount eaten by birds; Precipitation - precipitation; Precipitation eff - precipitation effect on water plants; Temperature - temperature; Temperature eff-temperature effect on water plants; Transparency - water transparency; Under $w$ plant rate - under water plant rate on water plant; Vegetation per - vegetation period; Vol plant eff - water plant volume effect; Vol plants - water plant volume; Water l eff - water level effect on water plants; Water lev - water level; Water plants - amount of water plants; Water vol - water plant volume.

The increase in biomass of all water plant groups is connected with the plant vegetation period, water level fluctuations, amount of precipitation in the vegetation period, air temperature in the vegetation period, nitrogen and phosphorous relation in water and proportional distribution between underwater plants and surface water plants. Insignificant water level changes in the drainage basin of Lake Engure could cause significant changes in the water plant growth dynamics. Since the lake is very shallow, its ecosystem balance is very sensitive. Increase of water plants could increase the rate of natural decomposition and later could possibly change the water chemical composition and also bring about changes in food sources for various animal groups. It is difficult to evaluate the impact of water plants that are mechanically taken out of the ecosystem of Lake Engure, because the waste products of these plants no longer enter the ecosystem and therefore have no impact on the water chemical composition, on sedimentation processes and on plant and animal food sources. Plants that are naturally or mechanically taken out of the system's total stock can accumulate chemical compounds and nutrients that can provide an uninterrupted food chain and ecological pyramid. The water plant biomass steadily increases, decreasing the water surface area of Lake Engure, thereby causing changes in animal habits and changes in human economical activities.

Sub-model "Fish in Lake Engure". Another sub-model that we started to develop was the sub-model "Fish in Lake Engure" (Fig. 10). This sub-model defines the total stock of fish in the lake and it has one inflow and four outflows. The inflow describes the natural increase of fish in the lake. The outflow describes fish mortality from fishing, fish natural mortality, fish mortality that depends on food sources, and fish mortality that depends on bird activities. The natural increase of a fish population depends on its lifespan, on the available spawning spots and reproductive success. The alternating and constant parameters of the inflows sum up into the fish birth rate, which is then multiplied by the total quantity of fish in the simulation step. The fish mortality rate that depends on the availability of food sources is made of the zooplankton density coefficient, zoobenthos density coefficient and algae density coefficient that in sum result in the relevant fish death rate. The natural fish mortality depends only on the lifespan, on condition that they are not disturbed. The fish mortality from bird assaults depends on bird activity, the total number of birds and the total number of fish.

Qualitative long-term data of the studied areas are necessary for developing comprehensive system dynamic models of changes in ecosystem states. Data that represent meteorological and hydrological changes in the environment are available for a period of more than hundred years. Therefore, a comprehensive analysis of metrological and hydrological conditions is feasible, and it is also possible to broach a different hypothesis regarding the causes of these changes. Nowadays there is a theory that global climate change is connected with human social and economic activ- 


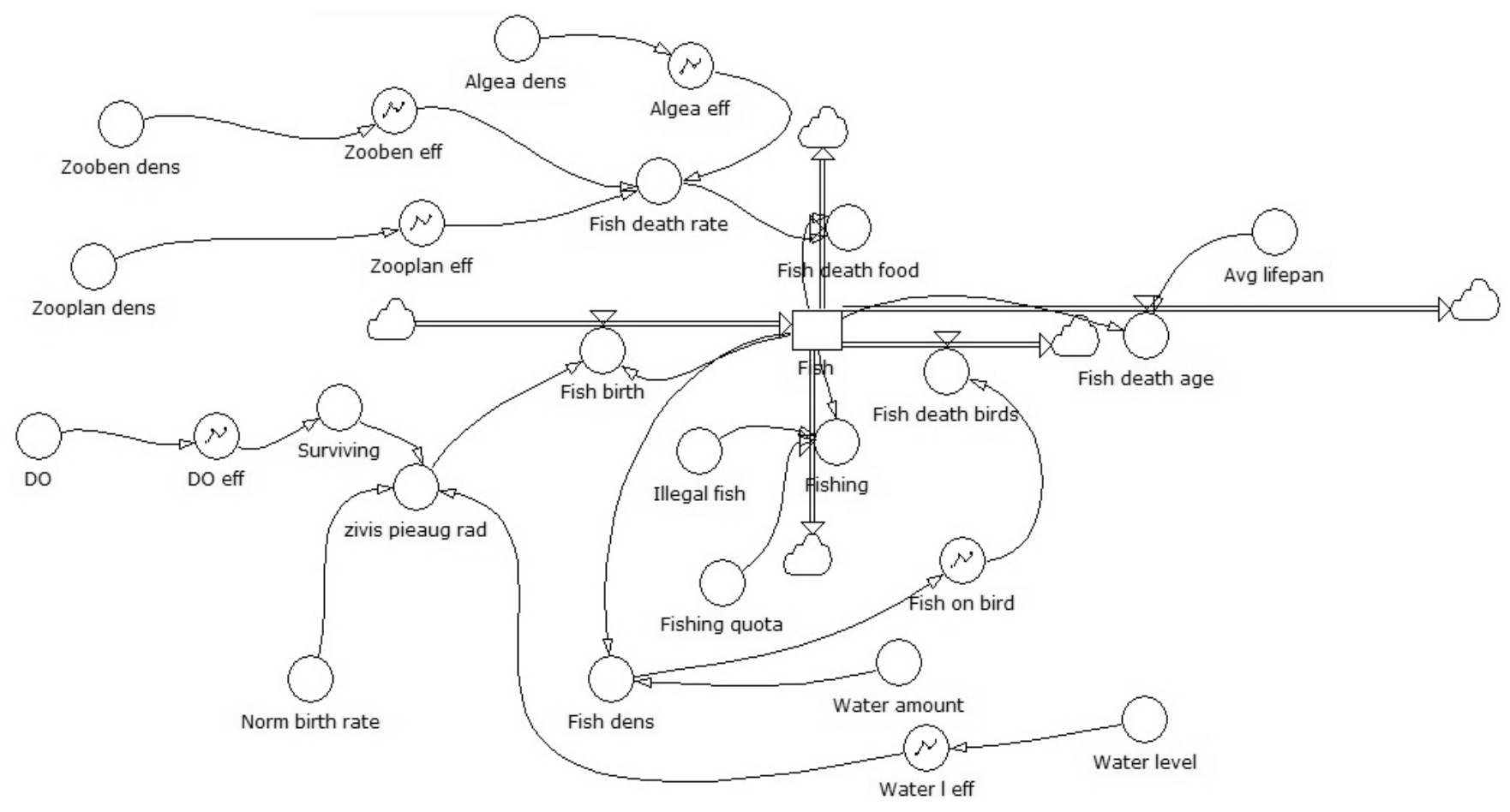

Fig. 10. The system dynamic sub-model "Fish in Lake Engure" scheme: Algae dens - algae density; Algae eff - alga density effect on fish mortality rate; Avg lifepan - average lifespan; DO - disolved oxigen; DO effe - disolved oxigen effect on fish mortality rate; Fish - fish amount; Fish birth - fish amount on birth; Fish mortality age - death fish by age; Fish mortality birds - fish death by birds; Fish death food - fish mortality by lack of food; Fish death rate fish mortality rate; Fish dens - fish density; Fish on bird - bird amount effect on fish amount; Fishing- amount mortality fish by fishing; Fishing quota fishing quota; Illegal fish - illegal fishing; Norm birth rate - normal fish birth rate; Surviving - surviving; Water amount - water amount; Water l eff - water level effect on fish birth rate; Water level - water level; Zooben dens - zoobenthos density; Zooben eff-zoobenthoss density on fish birth rate; Zooplan dens - zooplankton density; Zooplan eff - zooplankton density effect on fish birth rate.

ities that increase the impact on ecosystems and parameters that characterise ecoregions. There are various parameters that have impacts on ecosystems and that cannot be defined quantitatively, including the specific number of fish in water bodies, the quantity of flowers and total biomass volume in meadows, and so on. It would be very expensive and time-consuming to conduct studies of ecosystem changes that are characterised by such specific parameters. The counting of big mammals in the monitoring period is easy, whereas to estimate the precise small mammal (mice, polecat and others) stock is very complicated. It is practically impossible to determine the quantities of bugs, grubs and other small animals. It is also an expensive and time-consuming process to evaluate geological and soil structure changes. Thus, we need to consider the effectiveness and usefulness of this kind of research. Ecosystems that consist of one or more water bodies are problematic from the viewpoint of evaluation, as the total volume of water in rivers, lakes or oceans is an approximately taken parameter. For developing ecosystem models, we can use sub-models that had been developed before; so, there is a possibility to have qualitative results in simulations and other involved research processes.

\section{DISCUSSION}

Changes in bird populations are caused by various factors that can hardly be summarised and make a complicated and hardly definable system. One of the complicated system parameters is bird intellectual quality and ability to adapt to various changes in the environment. The main impacts that change bird population dynamics are connected with a proportional distribution of natural food and anthropogenic food changes. Till the $1990 \mathrm{~s}$, birds were feeding mostly from anthropogenic food sources, but after that - from natural food sources. This situation was caused by changes in the economic situation when the USSR collapsed. One of the reasons of dramatic fluctuations in bird populations is fur animal farm elimination in the early 1990s (Viksne, 1997).

Each formula included in the system dynamic model describes the behaviour of associated elements that interact with other elements; this requires a serious system analysis. The developed formula describes bird natality and mortality depending on changes in natural and anthropogenic food sources and bird mortality depending on predator assaults and hunting. Literature sources (Kḷaviņš et al., 2011b; Vīksne et al., 2011; Birzs, 2011; Gavrilova et al., 2011) clarify the interconnections between the number of bird nesting sites and bird mortality, between the density of zoobenthos and bird mortality, between the density of fish and bird mortality and between the available anthropogenic food and bird mortality. The developed formulas were entered into the PowerSim Studio 9.0 software for processing. These formulas form a complex algorithm system, which 
enables us to predict possible bird population changes. The simulated sub-model data were compared with the real time-data, proving that the model does basically work. Consequently, we can assume that in time it would be possible to develop a comprehensive model of the drainage basin ecosystem of Lake Engure. Comparing the total quantity of birds in the simulation with the observed data, we can see that the simulation shows a larger quantity of birds than the observed data (Fig. 7). From the beginning of the simulation till the $21^{\mathrm{st}}$ simulation year (observed time 1970), changes in the bird population matches, whereas starting from the $22^{\text {nd }}$ simulation year, offsets can be observed. This mismatch could be explained by the fact that in real time there are some relevant factors that affect the total birth rate of birds and that has not been measured qualitatively. This situation results in mismatches in the whole simulation time. Possibly, at that time, the predator assaults were more intense, affecting this fluctuation of total bird population.

The system dynamic sub-models of ecosystems and processes in Lake Engure are not developed at a highly detailed level. They represent a conceptual reflection on influencing processes and interactions among them. The final system dynamic model of ecosystems of Lake Engure should include a sub-model that would represent changes in water chemical composition, changes in water trophic state, changes in water plant, algae, zoobenthos and zooplankton growth dynamics and also changes in fish, bird and other animal population dynamics. A schematic image of full system dynamic model of ecosystems of Lake Engure would require about two hundred variables which together make a complex system. These parameters would interact with each other to make an uninterrupted chain system. In case of interruption, there is a likelihood that the developed system dynamic model does not function, which means that we would have to search for new alternative solutions to solve the system dynamic model problems.

The most complex variable in the sub-model "Birds in Lake Engure" was to evaluate the bird death rate related to food availability. This variable consists of tree interaction graphs, defining the zoobenthos density impact on bird mortality, the anthropogenic food availability impact on bird mortality and the fish density impact on bird mortality. The latter consists of the actual fish density and the coefficient of bird mortality. The zoobenthos density impact on bird mortality consists of the actual fish density and the coefficient of bird mortality. The available anthropogenic food impact on bird mortality consists of the actual fish density and the coefficient of bird mortality. The bird mortality caused by predator assaults depends on the number of predators in the simulation step. Additionally, the number of birds hunted each year is approximately equal to other years' percentage of hunted birds (Viksne, 1997).

Some problems that were discovered in the process of developing the sub-model "Birds in Lake Engure" were related to the estimation of the precise stock value of birds in the lake drainage area and the variables connected with the bird birth and mortality rates. The bird birth rate depends on the normal bird birth rate and the key variable of nesting site availability. The precise number of nesting sites cannot be estimated, just like the interrelation between nesting sites and their impact on the birth rate of birds. The latter also includes data of bird lifespan, which depends of the average bird lifespan and specific characters of particular species. The percentage of birds that eat fish can fluctuate depending on the number of birds of specific species. The percentage of birds who eat zooplankton and zoobenthos can fluctuate also depending on the number of birds of specific species.

Specific data that define water chemical compound changes in the model are part of a complicated process, because this part of the model is very sensitive to changes in other sub-models, and other changing parameters can cause serious changes in the water chemical state. Specific data include data on chemical compound concentrations in water and concentration change interactions affected by direct and indirect parameters. It is easy to monitor changes in water chemical and physical state; however, to define precise interactions between them is a more complicated task, and it is one of the main aims for developing system dynamic models of this kind (Klavin̄š et al., 2011a).

Qualitative long-term data from studied areas are necessary for developing comprehensive system dynamic models of changes in ecosystem states. Data that represent meteorological and hydrological changes in the environment are available for a period of more than hundred years. Therefore, a comprehensive analysis of metrological and hydrological conditions is feasible, and it is also possible to broach a different hypothesis regarding the causes of these changes. Nowadays there is a theory that global climate change is connected with human social and economic activities that increase the impact on ecosystems and parameters that characterise ecoregions. There are various parameters that have impacts on ecosystems and that cannot be defined quantitatively, including the specific number of fish in water bodies, the quantity of flowers and total biomass volume in meadows, and so on. It would be very expensive and time-consuming to conduct studies of ecosystem changes that are characterised by such specific parameters. The counting of big mammals in the monitoring period is easy, whereas to estimate the precise small mammal (mice, polecat and others) stock is very complicated. It is practically impossible to determine the quantities of bugs, grubs and other small animals. It is also an expensive and time-consuming process to evaluate geological and soil structure changes. So we need to consider the effectiveness and usefulness of this kind of research. Ecosystems which consist of one or more water bodies are problematic from the viewpoint of evaluation, as the total volume of water in rivers, lakes or oceans is an approximately taken parameter. For developing ecosystem models, we can use sub-models that had been developed before; so, there is a possibility to have qualitative results in simulations and other involved research processes (Jųrgensen, 2010).

Algae and water plant modelling is a more complicated process, because it is difficult to evaluate precise stock values 
of plants and algae. There is a possibility to calculate these values theoretically or develop correlation blocks. Some of the variables that are difficult to define are the algae growth rate and the water plant growth rate, because these variables consist of several parameters and, when they are changing, they affect the whole variable and cause misbalance in the system (Birzs, 2011). Furthermore, one of the reasons why it is difficult to define these variables is that water plants and algae are very sensitive of meteorological changes. Accordingly, there is a necessity of well-defined interactions between meteorological changes and water plant and algae dynamics (Kḷavin̄šs et al., 2011).

Some variables that are extremely difficult to evaluate are the stock values of zoobenthos and zooplankton, and they can bring in inaccuracies in developing this sub-model. The growth rates for these variables also consist of different parameters that, if changed, could change other interacting variables. In the final model, this sub-model has an important role in providing the food chain.

The process of system dynamic modelling of different ecosystems may be difficult because of the lack of complex data. For developing other sub-models, for example, the sub-models "Water plants in Lake Engure" and "Fish in Lake Engure", complicated data of ecosystem analysis are needed, and there is also the need for research in these study areas. If we want to develop a comprehensive system dynamic model of Lake Engure, sub-models should be prepared so that they are connectable with other sub-models.

\section{REFERENCES}

Anderson, V., Johnson, L. (1997). System Thinking Basics. Cambridge, MA: Pegasus Communications, 273 pp. (at pp. 46-51).

Anonīms (2009). Ilggadīgo zoobentosa organismu novērojumu analīze Engures ezerā. Zoobentosa daudzums Engures ezerā [Analysis of long-term observations of zoobenthos organisms in Lake Engure. Amount of zoobenthos in Lake Engure].

http://kalme.daba.lv/faili/konferences_seminari/2007/LU65_zin_konfere nce/Prezent_LU65_konf_sekc_KLIMATA_MAINIBA_UN_UDENI/Par eleE.pdf (in the text, Ilggadigie noverojumi, 2009) (last accessed 14.03.2013) (in Latvian).

Birzs, J. (2011). Dynamics of emergent macrophytes for 50 years in the coastal Lake Engure, Latvia. Proc. Latvian Acad. Sci. Sect. B, 65 (5/6), 170-178.

Blumberga, A. (ed.). (2010a). Sistēmdinamika vides inženierzinātnu studentiem [System Dynamics for Environmental Engineering Students]. Rìga: RTU Vides aizsardzības un siltuma sistēmu institūts, 18., 39.-40., 54., 84.-95. lpp. (in Latvian).

Blumberga, A. (ed.) (2010b). Sistēmiskas domāāšanas integrēšana vides politika [Integration of Systemic Thinking in Environmental Policy]. Rīga: RTU Vides aizsardzības un siltuma sistēmu institūts, 124.-129. lpp. (in Latvian).

Burkhard, B., Müller, F. (2008). Driver-Pressure-State-Impact-Response. In: Jørgensen, S. E., Fath, B. D. (eds.). Encyclopedia of Ecology. Vol. 2. Ecological Indicators (pp. 967-970). Oxford: Elsevier.
Costanza, R., Voinov, A. (2001). Modeling ecological and economic systems with STELLA: Part III. Ecol. Modelling, 143, 1-2, 1-7.

Cowing, M. M., Paté-Cornell, M. E., Glynn, P. W. (2004). Dynamic modeling of the tradeoff between productivity and safety in critical engineering systems. Reliability Eng. Syst. Safety, 86 (3), 269-284.

Desholm, M. (2009). Avian sensitivity to mortality: Prioritising migratory bird species for assessment at proposed wind farms. J. Environ. Manag., 90, 2672-2679.

Eberhards, G., Saltupe, B. (2000). Geological history, relief and deposits of the Lake Engure (Engure) area along the Baltic Sea. Proc. Latvian Acad. Sci. Sect. B, 54 (5/6), 141-147.

Erickson, W. P., Johnson, G. D., Young, D. P. Jr. (2005). A summary and comparison of bird mortality from anthropogenic causes with an emphasis on collisions. Bird Conservation Implementation and Integration in the Americas: Proceedings of the Third International Partners in Flight Conference. Asilomar, California, USA. Departament of Agriculture.

Forrester, J. W. (1961). Industrial Dynamics. Cambridge: MIT Press. 464 pp.

Forrester, J. W. (1969). Urban Dynamics. Cambridge: MIT Press. 300 pp.

Forrester, J. W. (1971). World Dynamics. Cambridge: MIT Press. 142 pp.

Gavrilova, G., Laivins, M., Priede, A., Medene, A. (2011). Alien flora in the Lake Engure Nature Park. Proc. Latvian Acad. Sci. Sect. B, 65 (5/6), 146-154.

Gentile, J. H., Harwell, M. A., Cropper Jr., W., Harwell, C. C., DeAngelis, D., Davis, S., Ogdenc, J. C., Lirman, D. (2001). Ecological conceptual models: A framework and case study on ecosystem management for South Florida sustainability. Sci. Total Environ., 274, 231-253.

Jurrgensen, S. E. (2010). A review of recent developments in lake modelling. Ecol. Modelling, 221, 689-692.

Haberl, H., Gaube, V., Díaz-Delgado, R., Krauze, K., Neuner, A, Peterseil, J., Plutzar, Ch., Singh, S. J., Vadineanu, A. (2009). Towards an integrated model of socioeconomic biodiversity drivers, pressures and impacts. A feasibility study based on three European long-term socio-ecological research platforms. Ecol. Econ., 68 (6), 1797-1812.

Kḷaviņš, M., Kokorīte, I., Rodinovs, V., Avotniece, Z., Sprinğe, G., Briede, A. (2011a). Hydrometerological parameters and aquatic chemistry of Lake Engure: Trends of changes due to human impact and natural variability. Proc. Latvian Acad. Sci. Sect. B, 65 (5/6), 138-145.

Kḷaviņš, M., Puajte, A., Kokorīte, I., Kalniņa, L., Rodinovs, V., Ansone, L., Mazeika, J., Jankevica, M., Bogans, E., Svagere, A. (2011b). Reconstruction of past anthropogenic impact intensity in Lake Engure using sedimentary record analysis. Proc. Latvian Acad. Sci. Sect. B, 65 (5/6), 146-153.

Komatsu, E., Fukushima, T., Harasawa, H. (2007). A modelling approach to forecast the effect of long-term climate change on lake water quality. Ecol. Modelling, 209, 351-366.

Moody, D. L. (2005). Theoretical and practical issues in evaluating the quality of conceptual models: Current state and future directions. Data Knowl. Eng., 55, 243-276.

Smith, P. C, Ackere, A. (2002). A note on the integration of system dynamics and economic models. J. Econ. Dynamics Control, 26, 1-10.

Strautnieks, I., Grīne, I. (2011). Lake Engure catchment area as example of the interaction of natural conditions, settlement patern and economic activities. Proc. Latvian Acad. Sci. Sect. B, 65 (5/6), 117-126.

Suter, G. W. (1999a). Developing conceptual models for complex ecological risk assessments. Hum. Ecol. Risk Assess., 5 (2), 375-396.

Suter, G. W. (1999b). A framework for the assessment of ecological risks from multiple activities. Hum. Ecol. Risk Assess., 5 (2), 397-414.

Vīksne, J. (1997). The Bird Lake Engure. Riga, Jāṇa sēta. 109.

Vīksne, J., Janaus, M., Mednis, A. (2011). Factors Influencing the number of breeding water birds in Lake Engure, Latvia. Proc. Latvian Acad. Sci. Sect. $B, 65(5 / 6), 127-137$. 


\section{SISTĒMDINAMIKAS PIELIETOŠANA VIDES PROCESU MODELĒŠANĀ: ENGURES EZERA PIEMĒRS}

Rakstā aplūkotas sistēmdinamiskās modelēšanas iespējas, kuras var pielietot Engures ezera sateces baseina vides procesu modelēšanā. Aplūkoti sistēmdinamikas model̦u veidošanas pamatprincipi un to svarīgākie elementi un uzbūve. Raksta mērḳis ir iepazīstināt ar iespējamām ekosistēmu modelēšanas metodēm, kas ḷauj vispusīgi atspoguḷot ekosistēmas faktisko stāvokli un prognozēt tālāko procesu virzību ekosistēmās. Šis ekosistēmas modelēšanas paņēmiens dod iespēju atspoguḷot antropogēnos un dabiskos procesus, kas ietekmē ekosistēmas. Sistēmdinamiskie model̦i tiek veidoti, lai parādītu dažādu procesu savstarpējo mijiedarbību, kā arī novērtētu svarīgākos vidi ietekmējošos faktorus. Šī modeḷa darbības pamatā ir blokshēmu un algoritmu sistēmas, kas ar matemātisku funkciju palīdzību attēlo notiekošās izmaiņas grafisku sakarību vai tabulu veidā. Engures ezera sateces baseina gadījumā tiek meklētas kopsakarības starp faktoriem, kas veido dažādas ekosistēmas. Modeḷu veidošanai izmantota specializēta datorprogramma PowerSim Studio Academic 9.0. Modelī ietilpst visaptveroši dati par dažādām ekosistēmām, piemēram, ūdens ķīmiski fizikālie, hidroloǵiskie, bioloğiskie, ornitoloğiskie un citi parametri. Pēc šīs modelēšanas metodes izstrādes būs iespējams novērtēt dažādu procesu ietekmi uz biolog̣isko daudzveidību pētījumu teritorijā, ka arī, konstatējot būtiskas problēmas, uzlabot vides pārvaldības praksi apkārtējās pašvaldībās un risināt svarīgas problēmas citos reǵionos. 